\title{
Overfeeding energy upregulates peroxisome proliferator-activated receptor (PPAR)y-controlled adipogenic and lipolytic gene networks but does not affect proinflammatory markers in visceral and subcutaneous adipose depots of Holstein cows ${ }^{1}$
}

\author{
P. Ji, J. K. Drackley, ${ }^{2}$ M. J. Khan, and J. J. Loor ${ }^{2}$ \\ Department of Animal Sciences and Division of Nutritional Sciences, University of Illinois, Urbana 61801
}

\begin{abstract}
Our objective was to determine the effects of overfeeding energy on gene expression in mesenteric (MAT), omental (OAT), and subcutaneous (SAT) adipose tissue (AT) from nonpregnant and nonlactating Holstein cows. Eighteen cows were randomly assigned to either a low energy [LE, net energy for lactation $\left(\mathrm{NE}_{\mathrm{L}}\right)=1.35 \mathrm{Mcal} / \mathrm{kg}$ of dry matter $\left.(\mathrm{DM})\right]$ or high energy $\left(\mathrm{HE}, \mathrm{NE}_{\mathrm{L}}=1.62 \mathrm{Mcal} / \mathrm{kg}\right.$ of $\left.\mathrm{DM}\right)$ diets for $8 \mathrm{wk}$. Cows were then euthanized and subsamples of MAT, OAT, and SAT were harvested for transcript profiling via quantitative PCR of 34 genes involved in lipogenesis, triacylglycerol (TAG) synthesis, lipolysis, lactate signaling, transcription regulation, and inflammation. The interaction of dietary energy and AT depot was only significant for $L P L$, which indicated a consistent response among the 3 sites. The expression of key genes related to de novo fatty acid synthesis $(F A S N)$ and desaturation $(S C D)$ was upregulated by HE compared with LE. Other genes associated with those processes, such as ACLY, ACACA, ELOVL6, FABP4, GPAM, and $L P I N 1$, were numerically upregulated by HE. The expression of lipolytic (PNPLA2 and ABHD5) genes was upregulated and the antilypolytic lactate receptor HCAR 1 was downregulated with HE compared with LE. The putative transcription regulator THRSP was upregulated and the transcription regulator $P P A R G$ tended to be upregulated by HE, whereas $S R E B F 1$ was downregulated. Among adipocytokines, HE tended to upregulate the expression of $C C L 2$, whereas $I L 6 R$ was downregulated. Overall, results indicated that overfeeding energy may increase AT mass at least in part by stimulating transcription of the network encompassing key genes associated with de novo synthesis. In re-
\end{abstract}

\footnotetext{
Received July 25, 2013.

Accepted February 5, 2014.

${ }^{1}$ Supported in part by National Institute of Food and Agriculture (NIFA; Washington, DC) project ILLU-538-914.

${ }^{2}$ Corresponding authors: drackley@illinois.edu and jloor@illinois. edu
}

sponse to energy overfeeding, the expression of $P P A R G$ rather than $S R E B F 1$ was closely associated with most adipogenic or lipogenic genes. However, the transcriptional activity of these regulators needs to be verified to confirm their role in the regulation of adipogenesis or lipogenesis in bovine AT. Overfeeding energy also may predispose cows to greater lipolytic potential by stimulating expression of TAG hydrolysis genes while inhibiting signaling via hydroxycarboxylic acid receptor (HCAR1), which is a novel antilipolytic regulator. Our results do not support an overt inflammatory response in adipose tissues in response to an 8-wk energy overfeeding.

Key words: energy, adipose gene expression, lipogenesis, lipolysis

\section{INTRODUCTION}

The transition period is recognized as the most critical time of the lactation cycle for both the production and well-being of dairy cows (Drackley, 1999). Fatty liver and ketosis are metabolic disorders of high-producing cows that occur postpartum as a consequence of mal-adaptation of lipid and carbohydrate metabolism. Studies from our group and others have observed that overconsumption of dietary energy relative to requirements during the entire dry period or close-up dry period was associated with greater lipolysis and increased risk of ketosis and fatty liver postpartum (Rabelo et al., 2003; Dann et al., 2006; Janovick et al., 2011; Ji et al., 2012; Litherland et al., 2013). Excess energy during the close-up dry period resulted in greater expression of both lipolytic and lipogenic genes in subcutaneous adipose tissue (SAT), which indicated that prepartal overfeeding regulates lipid metabolism at least partly through transcriptional mechanisms (Ji et al., 2012). Visceral adipose tissues (VAT) associated with portaldrained viscera are also metabolically active during the transition period (Reynolds et al., 2003).

Research in humans and rodents has shown that metabolism of VAT is different from that of SAT (Smith 
and Zachwieja, 1999). For example, VAT is more sensitive to lipolytic stimuli (e.g., catecholamines) but less sensitive to antilipolytic stimulation (insulin) than SAT (Van Harmelen et al., 1997; Giorgino et al., 2005). In nonruminants, VAT metabolic activity varies more in response to differences in energy balance than does SAT (Bouchard et al., 1993). In addition, it has been well established that over-storage of VAT is causally associated with metabolic disease in humans and rodents; for example, hepatic steatosis, insulin resistance, and diabetes (Montague and O'Rahilly, 2000). However, at a transcription level, it is largely unknown how VAT in dairy cattle responds to energy overfeeding.

Accumulating evidence in studies with humans and rodents indicates that adiposity is linked to systemic low-grade chronic inflammation attributed to the release of a spectrum of proinflammatory cytokines from adipose tissue (AT) that are causally linked to metabolic disease (Hotamisligil, 2006). Accumulation of VAT seems more detrimental than that of SAT due to the greater secretion of proinflammatory cytokines and direct drainage to liver through the portal vein (Fontana et al., 2007). Omental and mesenteric AT in nonpregnant, nonlactating Holstein cows increased by 76 and $92 \%$, respectively, after an 8-wk overfeeding of energy (Drackley et al., 2014). A potential role for such factors in metabolic disorders of periparturient cows has been postulated (Drackley et al., 2005; Sordillo et al., 2009) but direct evidence is limited.

Bradford et al. (2009) subcutaneously injected recombinant bovine tumor necrosis factor $\alpha(\mathbf{T N F} \boldsymbol{\alpha})$ to late-lactation cows for $7 \mathrm{~d}$ and observed greater hepatic triacylglycerol (TAG) accumulation, which highlighted the potential involvement of inflammatory pathways in the development of fatty liver disease. Such an effect, and the inflammatory responsiveness of liver at the molecular level, was demonstrated recently in early postpartal cows challenged with LPS (Graugnard et al., 2013). A recent study from our laboratory provided evidence that SAT and VAT from dairy cows are immune-responsive to LPS challenge (Mukesh et al., 2010). However, it remains unknown whether AT of obese cows as result of energy overfeeding have the capacity to produce more proinflammatory cytokines than AT of leaner cows, and whether the VAT might have a more active endocrine potential than SAT in dairy cows.

The objective of the current study was to characterize the adipose depot-specific transcriptional response of pathways associated with lipogenesis, lipolysis, and adipocytokine synthesis in cows overfed energy. As described elsewhere (Drackley et al., 2014), the use of nonpregnant, nonlactating cows as a model for overfeeding facilitates the study of transcriptional mechanisms associated with dietary energy overfeeding both in SAT and VAT without drastic hormonal changes during the periparturient period.

\section{MATERIALS AND METHODS}

\section{Experimental Design, Animals, Diets, and Tissue Sampling}

All procedures were conducted under protocols approved by the University of Illinois Institutional Animal Care and Use Committee (Protocol No. 06194). Details of diets and management are presented in a companion paper (Drackley et al., 2014). Briefly, 18 nonpregnant, nonlactating Holstein cows $(\mathrm{BW}=656$ $\pm 29 \mathrm{~kg}$; dried off at 60 to $130 \mathrm{~d}$ postpartum) were blocked by initial BCS and previous experimental treatment (proprietary) and were randomly assigned within block to either a moderate energy diet (HE; $\mathrm{NE}_{\mathrm{L}}=1.62 \mathrm{Mcal} / \mathrm{kg}$ of $\left.\mathrm{DM}\right)$ or a controlled energy $\operatorname{diet}\left(\mathbf{L E} ; \mathrm{NE}_{\mathrm{L}}=1.35 \mathrm{Mcal} / \mathrm{kg}\right.$ of $\left.\mathrm{DM}\right)$ provided once daily at $0800 \mathrm{~h}$ as TMR for ad libitum intake. The HE diet contained $73.8 \%$ forage (DM basis) from alfalfa silage, alfalfa hay, and corn silage, whereas the LE diet contained $81.7 \%$ forage, including $40.5 \%$ wheat straw (see detailed ingredient composition and nutrient profile of diets in Drackley et al., 2014). Cows had free access to water. The experiment was conducted in an indoor freestall barn equipped with Calan gates (American Calan Inc., Northwood, NH) to monitor individual feed intake.

At the end of the 8-wk experiment, cows were euthanized at the diagnostic facilities of the College of Veterinary Medicine, University of Illinois (Urbana). All visceral organs, omental AT (OAT), mesenteric AT (MAT), and perirenal AT were dissected and weighed. Subsamples of SAT from the left side of the tail-head region, OAT, and MAT were harvested immediately following euthanasia and snap-frozen in liquid $\mathrm{N}_{2}$ until RNA extraction.

\section{RNA Extraction and Quality Assessment, Primer Design and Evaluation, Internal Control Gene Selection, and Quantitative PCR}

Complete details of RNA extraction, quality assessment, and cDNA preparation are found in the supplemental file (http://dx.doi.org/10.3168/jds.2013-7295). Genes tested in the current study are listed in Table 1. Primers were designed and evaluated as previously described (Bionaz and Loor, 2008). The details of primer design, sequences, verification, and the description of genes measured are shown in Supplemental Table S1 (http://dx.doi.org/10.3168/jds.2013-7295). 
Table 1. The gene symbol for full gene names recorded in National Center for Biotechnology Information (NCBI; http://www.ncbi.nlm.nih.gov/gene)

\begin{tabular}{|c|c|}
\hline Gene symbol & Gene name in NCBI \\
\hline ABHD5 & Abhydrolase domain containing 5 \\
\hline$A C A C A$ & Acetyl-Co A carboxylase $\alpha$ \\
\hline$A C L Y$ & ATP citrate lyase \\
\hline$A C S L 1$ & Acyl-CoA synthetase long-chain family member 1 \\
\hline$A D R B 2$ & Adrenoceptor $\beta 2$, suface \\
\hline$A D F P / P L I N 2$ & Perilipin 2 \\
\hline$A D I P O Q$ & Adiponectin \\
\hline CD36 & Thrombospondin receptor \\
\hline CCL2 & Chemokine (C-C motif) ligand 2 \\
\hline CCL5 & Chemokine (C-C motif) ligand 5 \\
\hline ELOVL6 & Elongation of long chain fatty acids family member 6 \\
\hline$F A S N$ & Fatty acid synthase \\
\hline $\mathrm{FABP}_{4}$ & Adipocyte fatty acid binding protein 4 \\
\hline GPAM & Mitochondrial glycerol-3-phosphate acyltransferase \\
\hline HCAR1/GPR 81 & Hydroxycarboxylic acid receptor 1 \\
\hline$I L 1 B$ & Interleukin-1 $\beta$ \\
\hline IL 6 & Interleukin-6 \\
\hline$I L 6 R$ & Interleukin- 6 receptor \\
\hline$L E P$ & Leptin \\
\hline LIPE & Hormone sensitive lipase \\
\hline LPIN1 & Lipin 1 \\
\hline$L P L$ & Lipoprotein lipase \\
\hline$M G L L$ & Monoglyceride lipase \\
\hline$M L X I P L / C h R E B P$ & MLX interacting protein-like \\
\hline$P D E 3 B$ & Phosphodiesterase 3B, cGMP-inhibited \\
\hline PLIN1 & Perilipin 1 \\
\hline PNPLA2 & Patatin-like phospholipase domain containing 2 \\
\hline$P P A R G$ & Peroxisome proliferator-activated receptor gamma \\
\hline SAA3 & Acute-phase serum amyloid A3 \\
\hline$S C D$ & Stearoyl-CoA desaturase \\
\hline$S R E B F 1$ & Sterol regulatory element binding transcription factor 1 \\
\hline THRSP & Thyroid hormone responsive SPOT 14 \\
\hline$T_{L} R_{4}$ & Toll-like receptor 4 \\
\hline$T N F$ & Tumor necrosis factor $\alpha$ \\
\hline
\end{tabular}

Quantitative PCR. The quantitative (q)PCR reactions were performed in a MicroAmpOptical 384Well Reaction Plate (Applied Biosystems, Foster City, $\mathrm{CA})$. Within each well, $4 \mu \mathrm{L}$ of diluted cDNA combined with $6 \mu \mathrm{L}$ of a mixture composed of $5 \mu \mathrm{L}$ of 1 $\times$ SYBR Green master mix (Applied Biosystems), 0.4 $\mu \mathrm{L}$ each of $10 \mu M$ forward and reverse primers, and $0.2 \mu \mathrm{L}$ of DNase- and RNase-free water were added. Three replicates and a 6-point standard curve plus the no-template control were run for each gene to test the relative expression level (User Bulletin \#2, Applied Biosystems). The qPCR was conducted in an ABI Prism 7900 HT SDS instrument (Applied Biosystems) with the following conditions: $2 \mathrm{~min}$ at $50^{\circ} \mathrm{C}, 10 \mathrm{~min}$ at $95^{\circ} \mathrm{C}, 40$ cycles of $15 \mathrm{~s}$ at $95^{\circ} \mathrm{C}$ (denaturation), and 1 min at $60^{\circ} \mathrm{C}$ (annealing + extension). The presence of a single PCR product was verified by the dissociation protocol using incremental temperatures to $95^{\circ} \mathrm{C}$ for 15 $\mathrm{s}$, then $65^{\circ} \mathrm{C}$ for $15 \mathrm{~s}$.

Selection and Evaluation of Internal Control Genes. Complete details of the procedure to identify and select internal control genes (ICG) can be found in the supplemental file (http://dx.doi.org/10.3168/ jds.2013-7295). Briefly, candidate ICG were selected following the procedures described previously by Mukesh et al. (2010). The 3 ICG chosen out of 10 candidate genes were kelch-like ECH-associated protein 1 (KEAP1), tripartite motif-containing 41 (TRIM41), and mitochondrial ribosomal protein 63 (MRP63).

\section{Data Processing and Statistical Analysis}

The gene expression data were analyzed as a $2 \times$ 3 factorial arrangement in a completely randomized design. The raw quantity data for each gene from each sample generated from qPCR analysis were normalized by dividing the corresponding normalization factor calculated based on the geometric mean of the quantities of 3 ICG from the same sample using GeNorm software (http://medgen.ugent.be/ jvdesomp/ genorm/\#introduction). The normalized qPCR data (relative mRNA expression) were subjected to tests of normality and homogeneity of variance using the UNIVARIATE and GLM procedures of SAS (version 
9.1; SAS Institute Inc., Cary, NC), respectively. The normalized data of genes ADRB2, PNPLA2, ABHD5, $P L I N 1$, and $M G L L$ were subjected to square root transformation, whereas natural logarithmic transformation was applied for data of the remaining genes. The transformed data were tested with ANOVA using the MIXED procedure of SAS (SAS Institute Inc.) using a model that included the fixed effect of diet, AT depot, and the interaction. Cow within treatment was random term. The data were expressed as least squares means with SEM (Figures 1 to 4). Significant interactions were declared when $P \leq 0.10$ and significant main effects when $P \leq 0.06$. Tendencies for main effects are discussed when $P>0.06$ and $P<0.10$.

\section{Gene Network Analysis}

Ingenuity Pathway Analysis software (IPA; Redwood City, CA) was utilized to explore networks among the genes analyzed (Figure 4). This web-based software enables the reconstruction of networks and interactions among genes based on published literature from human, mouse, and rat genes and proteins. Use of IPA allows for easier interpretation and understanding of underlying relationships in a biologically relevant context. Before uploading data into IPA, relative expression levels of genes in MAT and OAT from SAS results were transformed to fold-change relative to that in SAT; the same transformation was performed on data from $\mathrm{HE}$ to obtain fold-changes compared with data from LE. A 1-fold change was set as the threshold to depict changes (i.e., genes shown in black indicate upregulation and those in white show downregulation) in gene expression between the tissues or treatments (Figure 4).

\section{RESULTS AND DISCUSSION}

Except for $L P L(P=0.05)$, no statistically significant interactions were detected between diet and adipose depot site. Therefore, our data indicate that both VAT and SAT responded in the same fashion to overfeeding energy. Using beef cattle, Faulconnier et al. (2007) also reported a lack of interaction between diet (grass-based or maize silage-based diets) and fat depot (intermuscular, SAT, and perirenal AT) for lipogenic enzyme (glucose-6-phosphate dehydrogenase, malic enzyme, fatty acid synthase, and glycerol-3-phosphate dehydrogenase) and lipoprotein lipase enzymatic activity. These results contrast with the findings of Baldwin et al. (2007), in which lipogenic genes in visceral fat depots (MAT and OAT) of growing beef steers were more responsive than those of SAT to increased dietary energy from different carbohydrate sources supplied either in the rumen or abomasum. In the subsequent sections, only the main effect of dietary energy will be discussed. The main effect of adipose depot on transcript profiles is reported in a companion paper (Ji et al., 2014).

\section{Effect of Overfeeding Energy on Lipogenic Gene Expression}

De Novo FA Synthesis. The mRNA expression of FASN was upregulated $(P=0.02)$, whereas that of ATP-citrate lyase $(A C L Y ; P=0.15)$ and $A C A C A$ $(P=0.14)$ were only numerically upregulated by energy overfeeding (Figure 1). This pattern of expression across AT sites indicated that, as a whole, the de novo FA synthesis (DNS) pathway was responsive to dietary energy changes, at least in part through transcriptional adaptation. The enzyme ACLY converts citrate to acetyl-CoA in the cytosol, which allows glucose and lactate carbon to serve as substrates for DNS. AcetylCoA carboxylase $(A C A C A)$ synthesizes malonyl-CoA from acetyl-CoA derived from either ruminal acetate or glucose, and FASN uses malonyl-CoA to in a series of elongation reactions leading to the formation of palmitic acid (Vernon, 1980). We speculate that these changes were probably induced by an increase in substrate availability (e.g., acetate, glucose, and lactate). In the present study, the HE diet contained greater proportions of ground-shelled corn (13.8 vs. $3.5 \%$ of dietary DM) and corn silage (50 vs. $28 \%$ of DM) compared with LE, which probably contributed to greater availability of DNS substrates.

Long-Chain FA Uptake, Activation, and Trafficking. In contrast to DNS-related genes, $L P L(P$ $=0.90), \operatorname{CD} 36(P=0.84)$, and ACSL1 $(P=0.72)$ were not affected by increasing energy intake (Figure 1). Expression of FABP 4 was only numerically $(P=$ 0.15) upregulated by feeding HE. Lipoprotein lipase and CD36 are involved in the uptake of preformed FA from chylomicrons or very low density lipoprotein, whereas ACSL1 is responsible for intracellular activation of long-chain FA (LCFA) for further processing (Thompson et al., 2010). Multifaceted functions of adipocyte fatty acid binding proteins (FABP4 is the adipose-specific isoform) have been identified in nonruminants, such as serving as chaperone protein for transporting intracellular LCFA to regulate lipid storage (Thompson et al., 2010), and during lipolysis as a partner of hormone-sensitive lipase (Shen et al., 1999). Despite the numerical increase in FABP4 in cows fed $\mathrm{HE}$, data suggest that energy overfeeding in the form of increased fermentable carbohydrate may have little effect on circulating LCFA incorporation in AT sites.

Elongation and Desaturation of LCFA. Energy overfeeding increased $(P=0.01)$ the expression of $S C D$ regardless of adipose depot but only resulted in a nu- 

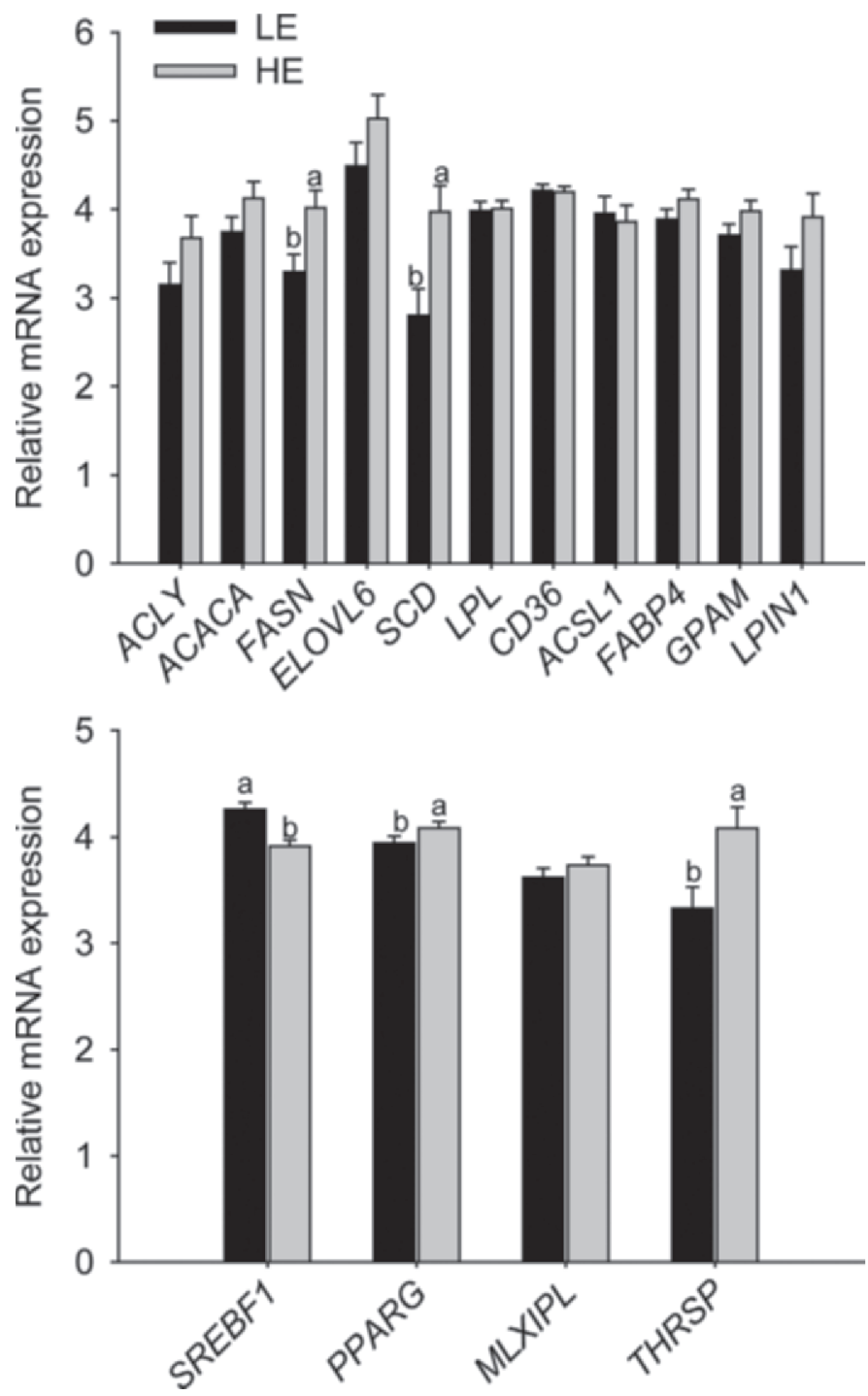

Figure 1. Main effect of dietary energy on mRNA expression of genes involved in de novo FA synthesis, long-chain FA transport, triacylglycerol (TAG) synthesis (panel A), and transcription regulation (panel B). Different letters indicate significant differences $(P \leq 0.06)$. The $\mathrm{x}$-axis indicates the official gene symbol from the National Center for Biotechnology Information (NCBI; http://www.ncbi.nlm.nih.gov/ gene; see Table 1 for gene names); the y-axis indicates relative mRNA expression value from natural logarithmic transformed data. $\mathrm{HE}=$ moderate energy diet $\left(\mathrm{NE}_{\mathrm{L}}=1.62 \mathrm{Mcal} / \mathrm{kg}\right.$ of $\left.\mathrm{DM}\right) ; \mathrm{LE}=$ controlled energy diet $\left(\mathrm{NE}_{\mathrm{L}}=1.35 \mathrm{Mcal} / \mathrm{kg}\right.$ of $\left.\mathrm{DM}\right)$.

merical $(P=0.14)$ increase in expression of ELOVL6 (Figure 1). In monogastrics, both elongation of long chain fatty acids family member 6 (ELOVL6) and stearoyl-CoA desaturase (SCD) are localized in the endoplasmic reticulum and cooperate during synthesis of 18:0 and cis-9 18:1 in mice (Guillou et al., 2010). Activity of ELOVL6 elongates 16:0 and cis-9 16:1 to 18:0 and cis-9 18:1 (Jakobsson et al., 2006). In contrast, 18:0 rather than 16:0 is the preferred substrate for SCD activity in mice, and oleic acid is the predominant isomer of 18:1 in bovine adipose (Vernon, 1980).

The parallel upregulation of $S C D$ along with FASN and the numerically greater ELOVL6, as observed previously in overfed prepartal dairy cows (Janovick et al., 2009), suggests that the pathway of de novo FA synthesis in ruminant AT involves elongation of 16:0, as observed in bovine adipocytes in vitro (Burns et al., 2012), and a subsequent desaturation to cis-9 18:1; hence, these joint pathways possibly constitute (as in nonruminants) the major source of LCFA in bovine AT.

TAG Synthesis and Lipid Droplet Formation. In the present study, energy overfeeding resulted in a numerical upregulation of both $G P A M(P=0.14)$ and LPIN1 ( $P=0.13$; Figure 1). Glycerol-3-phosphate acyltransferase (GPAT) esterifies FA to the $s n-1$ position of glycerol-3-phosphate, which is the first and presumed rate-limiting step of TAG biosynthesis (Takeuchi and Reue, 2009). The mitochondrial isoform of GPAT (GPAM) is localized on the outer membrane of mitochondria, and is the only characterized isoform in bovine (NCBI: http://www.ncbi.nlm.nih.gov/gene/?term $=$ GPAT+bos+taurus). Lipin proteins function as phosphatidate phosphatases that convert phosphatidic acid to diacylglycerol during TAG synthesis. The gene encoding LPIN1 was previously reported to be the most highly expressed isoform in bovine mammary gland during lactation (Bionaz and Loor, 2008).

In summary, the response observed for genes involved in DNS and the numerical increases of genes associated with intracellular transport and TAG synthesis, regardless of AT site, are suggestive of a greater potential for the lipogenic "machinery" in AT of cows fed HE. Although BCS during the 8-wk period increased for both groups, final BCS at wk 7 did not differ between dietary treatments (Drackley et al., 2014). However, mass of MAT, OAT, and perirenal AT (hence TAG) was greater in the HE group than in the LE group (MAT: 21.5 and $11.2 \pm 1.9 \mathrm{~kg}$; OAT: 26.8 and $15.2 \pm$ 1.57; perirenal AT: 8.87 and $5.38 \pm 0.87$; Drackley et al., 2014). Thus, we speculate that the apparent discrepancy between gene expression, final BCS, and VAT mass might have been due to the fact that (1) BCS in 0.25 -point increments is not sensitive enough to capture biological differences in BCS between 2 groups, particularly because both groups were in positive energy balance; or (2) DNS-related lipogenic enzymes in SAT compared with VAT also are regulated via posttranslational modifications.

Lipolysis. Both PNPLA2 $(P=0.06)$ and ABHD5 $(P$ $=0.02)$ were upregulated in all AT depots in response to energy overfeeding, and the expression of $M G L L$ was only numerically greater $(P=0.15)$ with $\mathrm{HE}$ compared with LE (Figure 2). Energy overfeeding did not affect 
the expression of $P D E 3 B$ but resulted in lower expression $(P=0.04)$ of the lactate receptor HCAR1 (Figure $2)$. The components of the lipolytic pathway were not completely known until the discovery of patatin-like phospholipase domain-containing protein 2 (PNPLA2, previously known as $A T G L)$, its activator protein abhydrolase domain containing 5 (ABHD5), and their interactions with perilipins (PLIN1 and PLIN2). More recently, evidence for a role of lactate signaling via the hydroxyl-carboxylic acid receptor HCAR1 (or GPR81) as an antilipolytic cue has been reported (Cai et al., 2008; Liu et al., 2009). The detailed mechanisms of regulation of lipolysis have been described by Zimmermann et al. (2009). The results of the current study are consistent with our recent findings that overfeeding energy during the close-up period increased the expression of PNPLA2, ABHD5, and MGLL in SAT of dairy cows at $10 \mathrm{~d}$ prepartum and $7 \mathrm{~d}$ postpartum (Ji et al., 2012). We attributed the response to transcriptional regulation via the cross-talk of peroxisome proliferatoractivated receptor $\gamma(\mathbf{P P A R} \gamma)$ and CCAAT/enhancer binding protein $\alpha(\mathbf{C} / \mathbf{E B P} \boldsymbol{\alpha})$, which also increased in overfed cows (Ji et al., 2012).

The greater expression of PNPLA2 and ABHD5 seems in line with the numerically greater expression of FABP 4 and supports the existence of a greater potential for FA flux (e.g., recycling) within AT of overfed cows. A recent study with beef steers observed that a

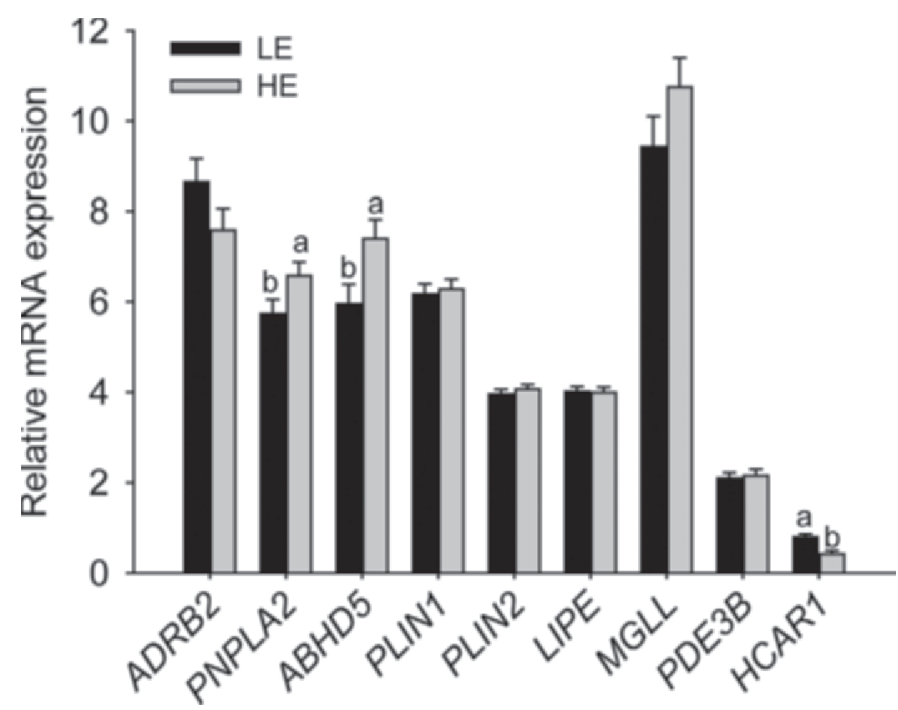

Figure 2. Main effect of dietary energy on mRNA expression of genes involved in lipolysis pathways. Different letters indicate significant differences $(P \leq 0.06)$. The $\mathrm{x}$-axis indicates the official gene symbol from the National Center for Biotechnology Information (NCBI; http://www.ncbi.nlm.nih.gov/gene; see Table 1 for gene names); the $\mathrm{y}$-axis indicates relative mRNA expression value from natural logarithmic transformed data. $\mathrm{HE}=$ moderate energy diet $\left(\mathrm{NE}_{\mathrm{L}}=1.62 \mathrm{Mcal} /\right.$ $\mathrm{kg}$ of $\mathrm{DM}) ; \mathrm{LE}=$ controlled energy $\operatorname{diet}\left(\mathrm{NE}_{\mathrm{L}}=1.35 \mathrm{Mcal} / \mathrm{kg}\right.$ of DM$)$. higher energy intake compared with control increased or tended to increase the in vitro release of glycerol from MAT and SAT without affecting LCFA release (Baldwin et al., 2007). The authors attributed this to greater activity of intracellular re-esterification that was compensatory to lipolysis when the steers were in positive energy balance (Baldwin et al., 2007). The lower expression of HCAR1 agrees with previous work in monogastrics demonstrating that excess fat deposition leads to downregulation of this receptor (Wanders et al., 2012). From a mechanistic standpoint, lower $H C A R 1$ could also dampen the antilipolytic effect of insulin (Ahmed et al., 2010).

Our results agree with posttranslational modification as a dominant mechanism regulating lipolysis in dairy cows, as reported by Koltes and Spurlock (2011) and Khan et al. (2013). However, an increase in lipolytic gene expression and the decrease in the antilipolytic $H C A R 1$ in response to energy overfeeding potentially predispose dairy cows to unfavorable metabolic states, which may manifest during negative energy balance when posttranslational mechanisms favoring lipolysis are activated.

\section{Transcriptional Regulation of Lipogenesis and Adipogenesis}

In cows fed HE, mRNA of THRSP $(P=0.01)$ was upregulated and that of PPARG tended $(P=0.10)$ to be upregulated (Figure 1) concurrently with some of the lipogenic genes. In contrast, expression of $S R E B F 1$ was downregulated $(P=0.001)$ and that of $M L X I P L$ (also known as ChREBP) was not affected $(P=0.35)$ by HE (Figure 3$)$. Peroxisome proliferatoractivated receptor gamma, ChREBP, and SREBF1 are the most-studied transcription factors that regulate adipogenic and lipogenic gene expression (Girard et al., 1997; Rosen and Spiegelman, 2000). As discussed above, the increased dietary energy density in HE was primarily derived from greater amounts of starch; thus, it is reasonable to deduce that cows fed that diet likely had a greater entry rate of glucose from either greater postruminal absorption or increased gluconeogenesis from propionate. This supposition is partly reflected by the tendency for greater serum insulin concentrations ( 28.8 and $21.9 \pm 2.78 \mu \mathrm{IU} / \mathrm{mL}$ for $\mathrm{HE}$ and $\mathrm{LE}$ ) in the face of unchanged glucose concentration in these cows (Drackley et al., 2014).

Based primarily on studies from rodent models, 2 possible mechanisms of transcriptional regulation of lipogenic genes in AT can be proposed in response to increased postabsorptive glucose availability. First, increased intracellular glucose uptake by adipocytes can directly activate the nuclear translocation of ChREBP 


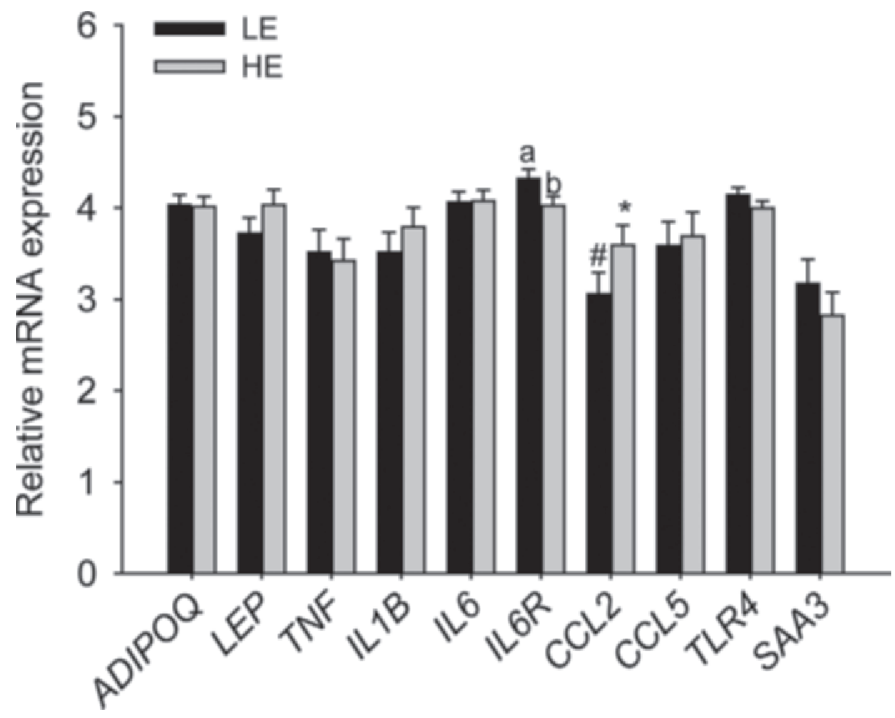

Figure 3. Main effect of dietary energy level on mRNA expression of adipokines, chemokines, and a cytokine receptor. Different letters indicate significant differences $(P \leq 0.06)$ and different symbols denote a tendency $(P=0.08)$ for differences. The $\mathrm{x}$-axis indicates the official gene symbol from the National Center for Biotechnology Information (NCBI; http://www.ncbi.nlm.nih.gov/gene; see Table 1 for gene names); the $\mathrm{y}$-axis indicates relative mRNA expression value from natural logarithmic transformed data. $\mathrm{HE}=$ moderate energy $\operatorname{diet}\left(\mathrm{NE}_{\mathrm{L}}=1.62 \mathrm{Mcal} / \mathrm{kg}\right.$ of $\left.\mathrm{DM}\right) ; \mathrm{LE}=$ controlled energy $\operatorname{diet}\left(\mathrm{NE}_{\mathrm{L}}\right.$ $=1.35 \mathrm{Mcal} / \mathrm{kg}$ of DM).

(ChREBP- $\alpha$ isoform), which triggers transcription of several lipogenic genes as well as $C h R E B P-\beta$, a novel and potent isoform recently identified (Herman et al., 2012). Thus, in rodent AT, the mRNA expression of $M L X I P L(C h R E B P)$ is positively correlated with the expression of both GLUT4 and its transcriptional targets (e.g., FASN and ACACA; Herman et al., 2012). In our study, 2 key murine ChREBP target genes (FASN, $S C D$ ) were coordinately upregulated in response to energy-overfeeding. However, the lack of change of MLXIPL expression in cows fed HE would argue against these genes being targets of ChREBP.

A second possible mechanism is that increased postabsorptive glucose availability can indirectly stimulate lipogenic gene expression through inducing insulin release, which consequently stimulates adipogenesis by activation of a cascade of transcription factors (TF) including $\mathrm{C} / \mathrm{EBP}, \mathrm{SREBF} 1$, and PPAR $\gamma$. These TF orchestrate the expression of lipogenic genes and maturation of adipocytes that are able to actively accumulate lipid (Rosen and Spiegelman, 2000). Among all TF, PPAR $\gamma$ and SREBF1 have been characterized as most important in terms of regulating glucose and lipid metabolism in lipogenic organs.

Insulin can directly induce expression and transcriptional activity of SREBF1, which targets several lipogenic genes (e.g., ACLY, ACACA, FASN, and GPAM;
Rosen and Spiegelman, 2000). In addition, during the fed state, the activated SREBF1 can trigger mRNA expression of itself as a consequence of increased insulin (Horton et al., 2002). However, the role of SREBF1 in regulation of lipogenesis was established based on a series of studies in liver or isolated hepatocytes from rodents (Horton et al., 2002). The fact that feeding HE resulted in lower SREBF1 expression but greater lipogenic gene expression casts doubt on the importance of this $\mathrm{TF}$ in regulating lipogenesis in bovine $\mathrm{AT}$ as demonstrated previously in rodents (Sekiya et al., 2007). Obviously, our data cannot rule out any posttranslational modification that might determine transcriptional activity of SREBF1.

The best characterized aspect of differentiation of adipocytes is the sequential cascade of the expression of $\mathrm{TF}$ that converge at PPAR $\gamma$ and $\mathrm{C} / \mathrm{EBP} \alpha$ to coordinate expression of adipogenic genes [e.g., $F A B P 4$ and insulin-induced glucose transporter (SLC2A4 or formerly known as GLUT4); Rosen and Spiegelman, 2000]. Recent studies utilizing chromatin immunoprecipitation coupled with either deep sequencing or whole-genome tiling arrays in rodent adipocytes unveiled thousands of PPAR $\gamma$ :retinoid X receptor (RXR) binding sites, which are particularly abundant in the vicinity of genes involved in lipid and glucose metabolism (Lefterova et al., 2008). If PPAR $\gamma$ functions similarly as in rodents, the observed upregulation of PPARG in cows fed HE should partly contribute to its transcriptional control of adipogenesis or lipogenesis in bovine AT. However, it should be kept in mind that ligand activation of PPAR $\gamma$ protein is likely to be the major regulator of its function (i.e., alter expression of target genes).

Thyroid hormone is critical in the regulation of energy homeostasis and THRSP, which encodes a nuclear protein that rapidly responds to thyroid hormone (Kinlaw et al., 1995), and has been implicated in transcriptional regulation of the major lipogenic genes in mammals via an unknown mechanism. Blood thyroid hormone is correlated with energy balance in dairy cows (Capuco et al., 2001); thus, higher thyroid hormone secretion may be expected in cows overfed energy (HE), with a consequent increase in the transcription of THRSP. In the present study, THRSP mRNA expression in VAT depots (Ji et al., 2014) was positively correlated with $\mathrm{NE}_{\mathrm{L}}$ intake during the last $3 \mathrm{wk}$ (data not shown).

\section{Expression of Adipocytokines}

Although cows fed HE had greater final BW and greatly increased mass of VAT compared with those fed LE (Drackley et al., 2014), only CCL2 tended to be upregulated $(P=0.08)$ and $L E P$ was only numerically upregulated $(P=0.15)$ by overfeeding energy (Figure 


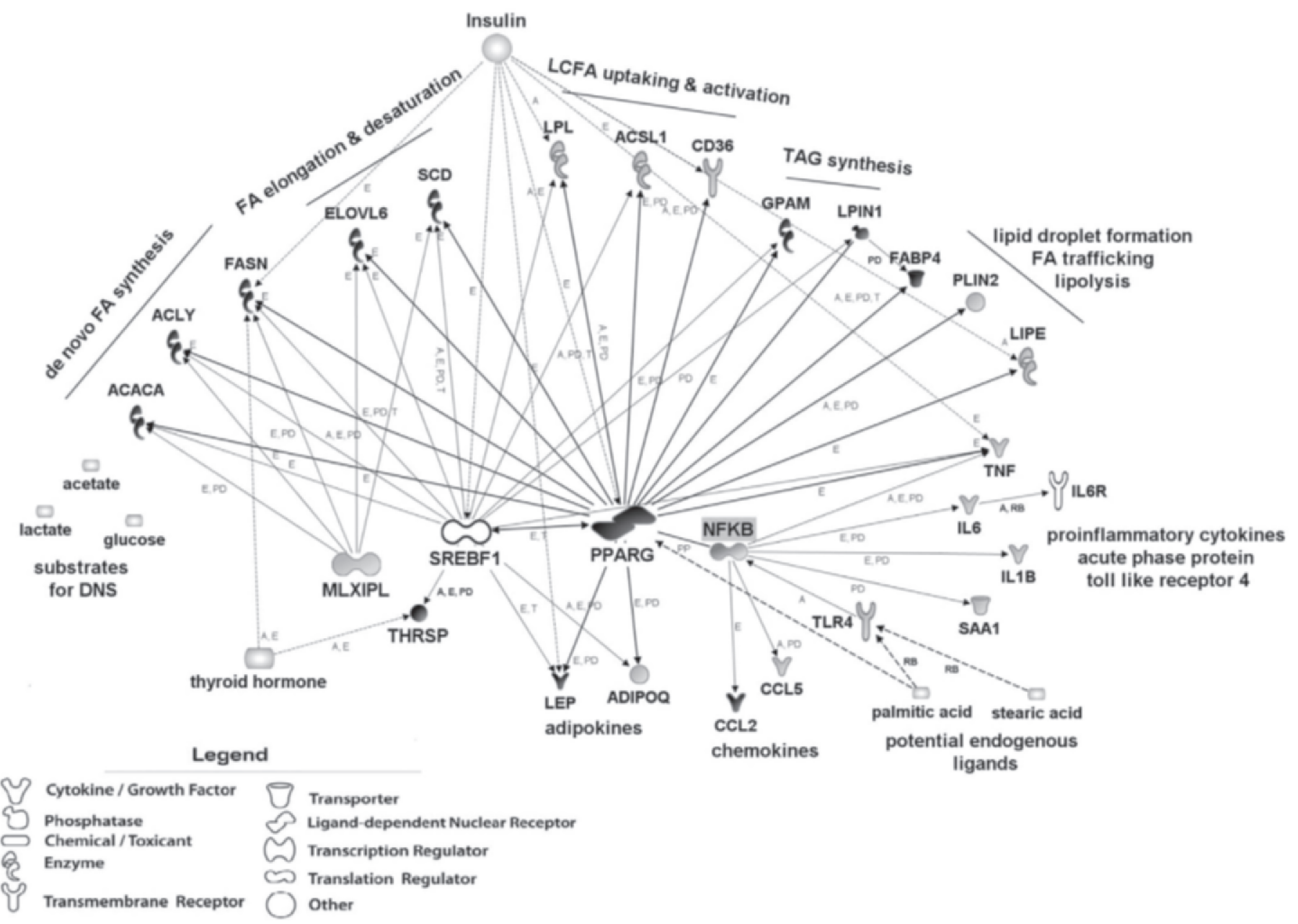

Figure 4. Putative network and changes in expression profile of genes in control vs. energy-overfed cows. Network was constructed with Ingenuity Pathway Analysis (IPA; Redwood City, CA) based on IPA knowledge base derived from literature published before 2011. Several putative relationships were edited according to recently published literature, which includes long-chain FA (palmitic and stearic acid) as endogenous ligands of toll-like receptor (TLR) 4 and peroxisome proliferator-activated receptor $\gamma$ (PPAR $\gamma$ ). Two hormones (insulin and thyroid hormone) were incorporated due to their potential role in regulation of several genes analyzed. Although not tested, nuclear factor kappa B (NFkB) was included in the network as it has a well-characterized role in regulating transcription of inflammation-related genes. Genes with a black background denote upregulation and white as downregulation $(P<0.05$; moderate energy vs. controlled energy diet); genes with gray background had no statistical change in mRNA expression between treatments. Letters along the edges denote effects at the level of activity (A), expression $(\mathrm{E})$, regulation of binding $(\mathrm{RB})$, protein-DNA binding $(\mathrm{PD})$, and transcription $(\mathrm{T})$.

3). Despite the lack of difference in $I L 6$ mRNA expression between dietary treatments, IL6 receptor $(I L 6 R)$ expression was lower $(P=0.06)$ due to energy overfeeding. The numerically greater serum insulin concentration observed in HE compared with LE cows (Drackley et al., 2014) supports the existence of a positive relationship of insulin with LEP expression (Chilliard et al., 2001).

Studies with human and rodent models demonstrated that adipocytes are capable of secreting various AT-specific adipokines (e.g., leptin and adiponectin), a spectrum of proinflammatory cytokines, chemokines, and acute phase proteins (Hotamisligil, 2006). Adipocytes also can respond to a multitude of inflammatory signals because they express ligand-binding receptors (e.g., IL-6R and TLR4). Besides adipocytes, AT is colonized with immune cells, primarily resident macrophages, which may be more important contributors to the inflammatory properties of AT depots (Hotamisligil, 2006). Therefore, it could be possible that the expression of non-AT-specific cytokines tested in our study could be derived from both adipocytes and immune cells.

Adipocyte hypertrophy increases CCL2 expression (Kamei et al., 2006). The gene CCL2 encodes a protein that is a member of the C-C motif chemokine family, identified as a chemoattractant, which increases macrophage infiltration in AT during obesity (Kanda et 
al., 2006). In the present study, the tendency for upregulation of $C C L 2$ expression with $\mathrm{HE}$ may be partly explained by greater numbers of differentiated adipocytes, which also was reflected by the greater expression of lipogenic genes (e.g., FASN) and the adipocyte differentiation marker $F A B P 4$.

The fact that proinflammatory cytokines (tumor necrosis factor- $\alpha$, IL-1 $\beta$, and IL-6) were not differentially expressed between dietary treatments could be related with the fact that upregulation of PPAR $\gamma$ expression inhibits nuclear factor $\kappa \mathrm{B}$, which is the major TF controlling proinflammatory cytokines (Ruan and Pownall, 2009). Whether the lower IL6R expression with HE is functionally related to inflammatory status remains to be determined, but it would support a lack of effect as opposed to what is often observed in obese nonruminants (Hotamisligil, 2006).

\section{CONCLUSIONS}

Regardless of AT depot, overfeeding energy relative to requirements stimulated expression of lipogenic genes to a greater extent than genes associated with uptake of preformed LCFA from blood (Figure 4). Despite the coordinated changes in mRNA expression of PPARG and a few of the lipogenic genes, the importance in transcriptional control of adipogenesis or lipogenesis in ruminant AT of the 3 most-studied TF (PPAR $\gamma$, SREBF1, and ChREBP) is still challenging. Thus, direct measurement of transcriptional activity of PPAR $\gamma$, SREBF1, and ChREBP merits further research. A similar conclusion could be discerned for THRSP, but its specific role in the overall process of AT remains unclear. The upregulation of PNPLA2 and $A B H D 5$, controlling the first and rate-limiting step of lipolysis, in response to energy overfeeding indicated that this process is, at least in part, controlled through transcriptional mechanisms at least in nonlactating and nonpregnant cows. We did not find strong evidence to support the hypothesis that overfeeding energy would stimulate an inflammatory response in bovine AT (Figure 4) as observed in obese nonruminants. Future studies should focus on the transcriptional and proteinlevel adaptations among the different fat depots to nutritional management during the peripartal period.

\section{ACKNOWLEDGMENTS}

We thank M. Bionaz (Animal and Rangeland Sciences, Oregon State University, Corvallis) for his help and guidance on the laboratory techniques employed in the current study and for providing input on the initial draft of the manuscript.

\section{REFERENCES}

Ahmed, K., S. Tunaru, C. Tang, M. Muller, A. Gille, A. Sassmann, J. Hanson, and S. Offermanns. 2010. An autocrine lactate loop mediates insulin-dependent inhibition of lipolysis through GPR81. Cell Metab. 11:311-319.

Baldwin, R. L. VI, K. R. McLeod, J. P. McNamara, T. H. Elsasser, and R. G. Baumann. 2007. Influence of abomasal carbohydrates on subcutaneous, omental, and mesenteric adipose lipogenic and lipolytic rates in growing beef steers. J. Anim. Sci. 85:2271-2282.

Bionaz, M., and J. J. Loor. 2008. Gene networks driving bovine milk fat synthesis during the lactation cycle. BMC Genomics 9:366.

Bouchard, C., J. P. Despres, and P. Mauriege. 1993. Genetic and nongenetic determinants of regional fat distribution. Endocr. Rev. 14:72-93.

Bradford, B. J., L. K. Mamedova, J. E. Minton, J. S. Drouillard, and B. J. Johnson. 2009. Daily injection of tumor necrosis factor- $\alpha$ increases hepatic triglycerides and alters transcript abundance of metabolic genes in lactating dairy cattle. J. Nutr. 139:1451-1456.

Burns, T. A., A. K. Kadegowda, S. K. Duckett, S. L. Pratt, and T. C. Jenkins. 2012. Palmitoleic (16:1 cis-9) and cis-vaccenic (18:1 cis-11) acid alter lipogenesis in bovine adipocyte cultures. Lipids 47:1143-1153.

Cai, T. Q., N. Ren, L. Jin, K. Cheng, S. Kash, R. Chen, S. D. Wright, A. K. Taggart, and M. G. Waters. 2008. Role of GPR81 in lactatemediated reduction of adipose lipolysis. Biochem. Biophys. Res. Commun. 377:987-991.

Capuco, A. V., D. L. Wood, T. H. Elsasser, S. Kahl, R. A. Erdman, C. P. Van Tassell, A. Lefcourt, and L. S. Piperova. 2001. Effect of somatotropin on thyroid hormones and cytokines in lactating dairy cows during ad libitum and restricted feed intake. J. Dairy Sci. 84:2430-2439.

Chilliard, Y., M. Bonnet, C. Delavaud, Y. Faulconnier, C. Leroux, J. Djiane, and F. Bocquier. 2001. Leptin in ruminants. Gene expression in adipose tissue and mammary gland, and regulation of plasma concentration. Domest. Anim. Endocrinol. 21:271-295.

Dann, H. M., N. B. Litherland, J. P. Underwood, M. Bionaz, A. D'Angelo, J. W. McFadden, and J. K. Drackley. 2006. Diets during far-off and close-up dry periods affect periparturient metabolism and lactation in multiparous cows. J. Dairy Sci. 89:3563-3577.

Drackley, J. K. 1999. Biology of dairy cows during the transition period: The final frontier? J. Dairy Sci. 82:2259-2273.

Drackley, J. K., H. M. Dann, G. N. Douglas, N. A. Janovick Guretzky, N. B. Litherland, J. P. Underwood, and J. J. Loor. 2005. Physiological and pathological adaptations in dairy cows that may increase susceptibility to periparturient diseases and disorders. Ital. J. Anim. Sci. 4:323-344.

Drackley, J. K., R. L. Wallace, D. Graugnard, J. Vasquez, B. F. Richards, and J. J. Loor. 2014. Visceral adipose tissue mass in nonlactating dairy cows fed diets differing in energy density. J. Dairy Sci. 97:3420-3430. http://dx.doi.org/10.3168/jds.2014-8014.

Faulconnier, Y., I. Ortigues-Marty, C. Delavaud, D. Dozias, R. Jailler, D. Micol, and Y. Chilliard. 2007. Influence of the diet and grazing on adipose tissue lipogenic activities and plasma leptin in steers. Animal 1:1263-1271.

Fontana, L., J. C. Eagon, M. E. Trujillo, P. E. Scherer, and S. Klein. 2007. Visceral fat adipokine secretion is associated with systemic inflammation in obese humans. Diabetes 56:1010-1013.

Giorgino, F., L. Laviola, and J. W. Eriksson. 2005. Regional differences of insulin action in adipose tissue: Insights from in vivo and in vitro studies. Acta Physiol. Scand. 183:13-30

Girard, J., P. Ferre, and F. Foufelle. 1997. Mechanisms by which carbohydrates regulate expression of genes for glycolytic and lipogenic enzymes. Annu. Rev. Nutr. 17:325-352.

Graugnard, D. E., K. M. Moyes, E. Trevisi, M. J. Khan, D. Keisler, J K. Drackley, G. Bertoni, and J. J. Loor. 2013. Liver lipid content and inflammometabolic indices in peripartal dairy cows are altered in response to prepartal energy intake and postpartal intramammary inflammatory challenge. J. Dairy Sci. 96:918-935.

Guillou, H., D. Zadravec, P. G. Martin, and A. Jacobsson. 2010. The key roles of elongases and desaturases in mammalian fatty acid 
metabolism: Insights from transgenic mice. Prog. Lipid Res. 49:186-199.

Herman, M. A., O. D. Peroni, J. Villoria, M. R. Schön, N. A. Abumrad, M. Blüher, S. Klein, and B. B. Kahn. 2012. A novel ChREBP isoform in adipose tissue regulates systemic glucose metabolism. Nature 484:333-338.

Hertzel, A. V., K. Hellberg, J. M. Reynolds, A. C. Kruse, B. E. Juhlmann, A. J. Smith, M. A. Sanders, D. H. Ohlendorf, J. Suttles, and D. A. Bernlohr. 2009. Identification and characterization of a small molecule inhibitor of fatty acid binding proteins. J. Med. Chem. 52:6024-6031.

Horton, J. D., J. L. Goldstein, and M. S. Brown. 2002. SREBPs: Activators of the complete program of cholesterol and fatty acid synthesis in the liver. J. Clin. Invest. 109:1125-1131.

Hotamisligil, G. S. 2006. Inflammation and metabolic disorders. Nature 444:860-867.

Jakobsson, A., R. Westerberg, and A. Jacobsson. 2006. Fatty acid elongases in mammals: Their regulation and roles in metabolism. Prog. Lipid Res. 45:237-249.

Janovick, N. A., Y. R. Boisclair, and J. K. Drackley. 2011. Prepartum dietary energy intake affects metabolism and health during the periparturient period in primiparous and multiparous Holstein cows. J. Dairy Sci. 94:1385-1400.

Janovick, N. A., J. J. Loor, P. Ji, R. E. Everts, H. A. Lewin, S. L. Rodriguez-Zas, and J. K. Drackley. 2009. Overfeeding energy prepartum dramatically affects peripartal expression of mRNA transcriptions in subcutaneous adipose tissue compared with controlling energy intake prepartum. J. Dairy Sci. 92(E-Suppl. 1):557. (Abstr.)

Ji, P., J. K. Drackley, M. J. Khan, and J. J. Loor. 2014. Inflammationand lipid metabolism-related gene network signatures in visceral and subcutaneous adipose depots of Holstein cows. J. Dairy Sci. 97:3441-3448. 10.3168/jds.2013-7296.

Ji, P., J. S. Osorio, J. K. Drackley, and J. J. Loor. 2012. Overfeeding a moderate energy diet prepartum does not impair bovine subcutaneous adipose tissue insulin signal transduction and induces marked changes in peripartal gene network expression. J. Dairy Sci. 95:4333-4351.

Kamei, N., K. Tobe, R. Suzuki, M. Ohsugi, T. Watanabe, N. Kubota, N. Ohtsuka-Kowatari, K. Kumagai, K. Sakamoto, M. Kobayashi, T. Yamauchi, K. Ueki, Y. Oishi, S. Nishimura, I. Manabe, H. Hashimoto, Y. Ohnishi, H. Ogata, K. Tokuyama, M. Tsunoda, T. Ide, K. Murakami, R. Nagai, and T. Kadowaki. 2006. Overexpression of monocyte chemoattractant protein-1 in adipose tissues causes macrophage recruitment and insulin resistance. J. Biol. Chem. 281:26602-26614.

Kanda, H., S. Tateya, Y. Tamori, K. Kotani, K. Hiasa, R. Kitazawa, S. Kitazawa, H. Miyachi, S. Maeda, K. Egashira, and M. Kasuga. 2006. MCP-1 contributes to macrophage infiltration into adipose tissue, insulin resistance, and hepatic steatosis in obesity. J. Clin. Invest. 116:1494-1505.

Khan, M. J., A. Hosseini, S. Burrell, S. M. Rocco, J. P. McNamara, and J. J. Loor. 2013. Change in subcutaneous adipose tissue metabolism and gene network expression during the transition period in dairy cows, including differences due to sire genetic merit. J. Dairy Sci. 96:2171-2182.

Kinlaw, W. B., J. L. Church, J. Harmon, and C. N. Mariash. 1995. Direct evidence for a role of the "spot 14" protein in the regulation of lipid synthesis. J. Biol. Chem. 270:16615-16618.

Koltes, D. A., and D. M. Spurlock. 2011. Coordination of lipid dropletassociated proteins during the transition period of Holstein dairy cows. J. Dairy Sci. 94:1839-1848.

Lefterova, M. I., Y. Zhang, D. J. Steger, M. Schupp, J. Schug, A. Cristancho, D. Feng, D. Zhuo, C. J. Stoeckert Jr., X. S. Liu, and M. A. Lazar. 2008. PPARgamma and C/EBP factors orchestrate adipocyte biology via adjacent binding on a genome-wide scale. Genes Dev. 22:2941-2952.

Litherland, N. B., D. N. da Silva, W. P. Hansen, L. Davis, S. Emanuele, and H. Blalock. 2013. Effects of prepartum controlled-energy wheat straw and grass hay diets supplemented with starch or sugar on periparturient dairy cow performance and lipid metabolism. J. Dairy Sci. 96:3050-3063.

Liu, C., J. Wu, J. Zhu, C. Kuei, J. Yu, J. Shelton, S. W. Sutton, X. Li, S. J. Yun, T. Mirzadegan, C. Mazur, F. Kamme, and T. W. Lovenberg. 2009. Lactate inhibits lipolysis in fat cells through activation of an orphan G-protein-coupled receptor, GPR81. J. Biol. Chem. 284:2811-2822.

Montague, C. T., and S. O'Rahilly. 2000. The perils of portliness: Causes and consequences of visceral adiposity. Diabetes 49:883888.

Mukesh, M., M. Bionaz, D. E. Graugnard, J. K. Drackley, and J. J. Loor. 2010. Adipose tissue depots of Holstein cows are immune responsive: Inflammatory gene expression in vitro. Domest. Anim. Endocrinol. 38:168-178

Rabelo, E., R. L. Rezende, S. J. Bertics, and R. R. Grummer. 2003 Effects of transition diets varying in dietary energy density on lactation performance and ruminal parameters of dairy cows. J. Dairy Sci. 86:916-925.

Reynolds, C. K., P. C. Aikman, B. Lupoli, D. J. Humphries, and D. E. Beever. 2003. Splanchnic metabolism of dairy cows during the transition from late gestation through early lactation. J. Dairy Sci. 86:1201-1217.

Rosen, E. D., and B. M. Spiegelman. 2000. Molecular regulation of adipogenesis. Annu. Rev. Cell Dev. Biol. 16:145-171.

Ruan, H., and H. J. Pownall. 2009. The adipocyte IKK/NFkappaB pathway: A therapeutic target for insulin resistance. Curr. Opin. Investig. Drugs 10:346-352.

Sekiya, M., N. Yahagi, T. Matsuzaka, Y. Takeuchi, Y. Nakagawa, H. Takahashi, H. Okazaki, Y. Iizuka, K. Ohashi, T. Gotoda, S. Ishibashi, R. Nagai, T. Yamazaki, T. Kadowaki, N. Yamada, J. Osuga, and H. Shimano. 2007. SREBP-1-independent regulation of lipogenic gene expression in adipocytes. J. Lipid Res. 48:1581-1591.

Shen, W. J., K. Sridhar, D. A. Bernlohr, and F. B. Kraemer. 1999 Interaction of rat hormone-sensitive lipase with adipocyte lipidbinding protein. Proc. Natl. Acad. Sci. USA 96:5528-5532.

Smith, S. R., and J. J. Zachwieja. 1999. Visceral adipose tissue: A critical review of intervention strategies. Int. J. Obes. Relat. Metab. Disord. 23:329-335.

Sordillo, L. M., G. A. Contreras, and S. L. Aitken. 2009. Metabolic factors affecting the inflammatory response of periparturient dairy cows. Anim. Health Res. Rev. 10:53-63.

Takeuchi, K., and K. Reue. 2009. Biochemistry, physiology, and genetics of GPAT, AGPAT, and lipin enzymes in triglyceride synthesis. Am. J. Physiol. Endocrinol. Metab. 296:E1195-E1209.

Thompson, B. R., S. Lobo, and D. A. Bernlohr. 2010. Fatty acid flux in adipocytes: The in's and out's of fat cell lipid trafficking. Mol. Cell. Endocrinol. 318:24-33.

Van Harmelen, V., F. Lönnqvist, A. Thörne, A. Wennlund, V. Large, S. Reynisdottir, and P. Arner. 1997. Noradrenaline-induced lipolysis in isolated mesenteric, omental and subcutaneous adipocytes from obese subjects. Int. J. Obes. Relat. Metab. Disord. 21:972-979.

Vernon, R. G. 1980. Lipid metabolism in the adipose tissue of ruminant animals. Prog. Lipid Res. 19:23-106.

Wanders, D., E. C. Graff, and R. L. Judd. 2012. Effects of high fat diet on GPR109A and GPR81 gene expression. Biochem. Biophys. Res. Commun. 425:278-283.

Zimmermann, R., A. Lass, G. Haemmerle, and R. Zechner. 2009. Fate of fat: The role of adipose triglyceride lipase in lipolysis. Biochim. Biophys. Acta 1791:494-500. 